\title{
Reticulate Nummulites (N. fabianii Linage) and Age of the Pellatispira-Beds of the Drazinda Formation, Sulaiman Range, Pakistan
}

\author{
Ozcan $\mathrm{E}^{1 *}$, Yücel $\mathrm{A0}^{1}$, Erbay $\mathrm{S}^{1}$, Less $\mathrm{G}^{2}$, Kaygili $\mathrm{S}^{3}$, Ali $\mathrm{N}^{4}$ and Hanif $\mathbf{M}^{5}$ \\ ${ }^{1}$ Department of Geological Engineering, Faculty of Mines, Istanbul Technical University \\ (ITU), Turkey \\ ${ }^{2}$ University of Miskolc, Institute of Mineralogy and Geology, Hungary \\ ${ }^{3}$ Department of Geological Engineering, Firat University, Elazig, Turkey \\ ${ }^{4}$ Department of Geology, University of Peshawar, Pakistan \\ ${ }^{5}$ National Centre of Excellence in Geology, University of Peshawar, Pakistan
}

\section{Research Article \\ Volume 2 Issue 1}

Received Date: January 08, 2019

Published Date: January 21, 2019

*Corresponding author: Ercan Ozcan, Department of Geological Engineering, Faculty of Mines, Istanbul Technical University (ITU), Maslak-34469 Istanbul, Turkey, Tel: +90 212 2856148; Email: ozcanerc@itu.edu.tr

\section{Abstract}

The Eocene shallow marine Pellatispira-beds in the upper part of the Drazinda Formation represent the latest phase of Cenozoic Tethyan marine deposition in the Sulaiman Range, West Pakistan. The unit consists of stratigraphically important taxa as Heterostegina, Silvestriella, Pellatispira, a new Baculogypsina (possibly ancestral to modern Baculogypsina) and reticulate Nummulites implying a latest middle to late Eocene (late Bartonian-Priabonian) age. A more precise age of the unit requires the biometric study of reticulate Nummulites, the evolutionary scheme of which is better known from the peri-Mediterranean region in the Tethys. This group, which was subdivided into a series of successive chrono-species based on the biometry of inner cross-diameter of proloculus and changes in the types of granulation/reticulation on the test surface in the late Eocene-late Oligocene interval, appears to have a significant biostratigraphic potential for a high-resolution biostratigraphy in the peri-Mediterranean region (Western Tethys). The reticulate Nummulites in two samples from Rakhi Nala and Zinda Pir, ZP22 and RNB10, were studied and compared with those from the peri-Mediterranean region. The isolated specimens have a weak surface granulation externally, a distinct small umbonal granule (pile) and typical reticulation. The samples ZP22 and RNB10 from Zinda Pir and and Rakhi Nala sections have an average inner cross diameter of proloculus of 152.0 and $153.0 \mu \mathrm{m}$ respectively. The reticulate Nummulites in both samples are assigned to $N$. hormoensis, a chrono-species characteristic for the shallow benthic zone (SBZ 18), referable to latest Bartonian-early Priabonian time interval. Since Heterostegina in peri-Mediterranean region and in Pakistan belongs to different lineages, a correlation of $N$. hormoensis in the studied samples with the wellestablished evolutionary scheme of Heterostegina reticulata and H. armenica lineages from the Western Tethys was not possible. 


\section{International Journal of Paleobiology \& Paleontology}

Keywords: Reticulate Nummulites; Biometry; Priabonian; Pellatispira-beds; Drazinda Formation; Pakistan

Abbreviations: ZP: Zinda Pir; LBF: Larger Benthic Foraminifera; SBZ: Shallow Benthic Zone; RNB: Rakhi Nala-B

\section{Introduction}

The late Bartonian-Priabonian boundary corresponds to a major faunal turnover in the Tethyan shallow marine ecosystems. Some new foraminiferal taxa, such as Heterostegina, Pellatispira, Silvestriella appear for the first time, while major groups of large Nummulites and alveolinids disappear during Bartonian and early Priabonian. A high-resolution dating of the shallow marine Priabonian deposits is, however, difficult due to the inadequate data showing the possible evolutionary changes in these foraminiferal taxa. Several groups, such as reticulate Nummulites and genus Heterostegina in the peri-Mediterranean region appear to have the potential for a better biostratigraphic subdivision of shallow marine deposits due to the morphological changes recorded in the internal part of the test and their morphometric characterization.

Reticulate Nummulites occur rather sporadically in the Pellatispira-beds, the highest part of the Drazinda Formation in the Sulaiman Fold Belt, West Pakistan (Figures $1 \& 2$ ). This group ( $N$. fabianii lineage) occurs in late Lutetian to lower Chattian shallow marine deposits in Tethys [1-6]. Although Nummulites fabianii lineage was relatively well studied for its morphometric aspects in the peri-Mediterranean region (from Europe to Turkey and Armenia) [2,4-5], very poor information is available for the Eocene representatives in Indian Subcontinent $[1,6]$. In the peri-Mediterranean region (Western Tethys) the evolutionary succession of Nummulites fabianii lineage consists of $N$. bullatus- $N$. garganicus- $N$. hormoensis- $N$. fabianii- N. fichteli- N. bormidensis, ranging in age from late Lutetian to early Chattian [7]. The evolution of this group in Western Tethys was quantifed based on the inner-cross diameter of the proloculus, ranging from 70 80 to almost more than $400 \mu \mathrm{m}[4,7]$. Type of the granulation on the test surface was also utilized in species discrimination.

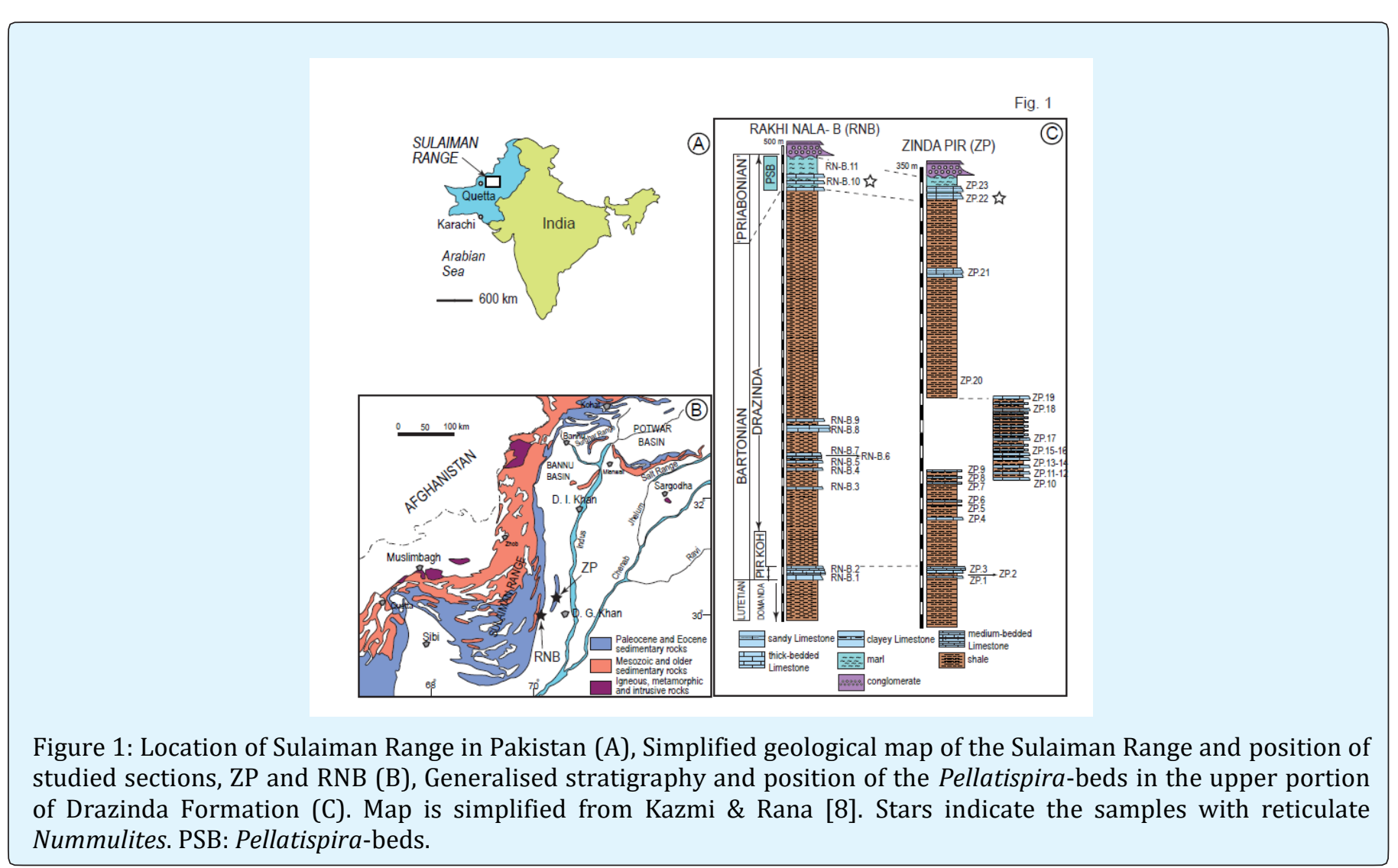




\section{International Journal of Paleobiology \& Paleontology}

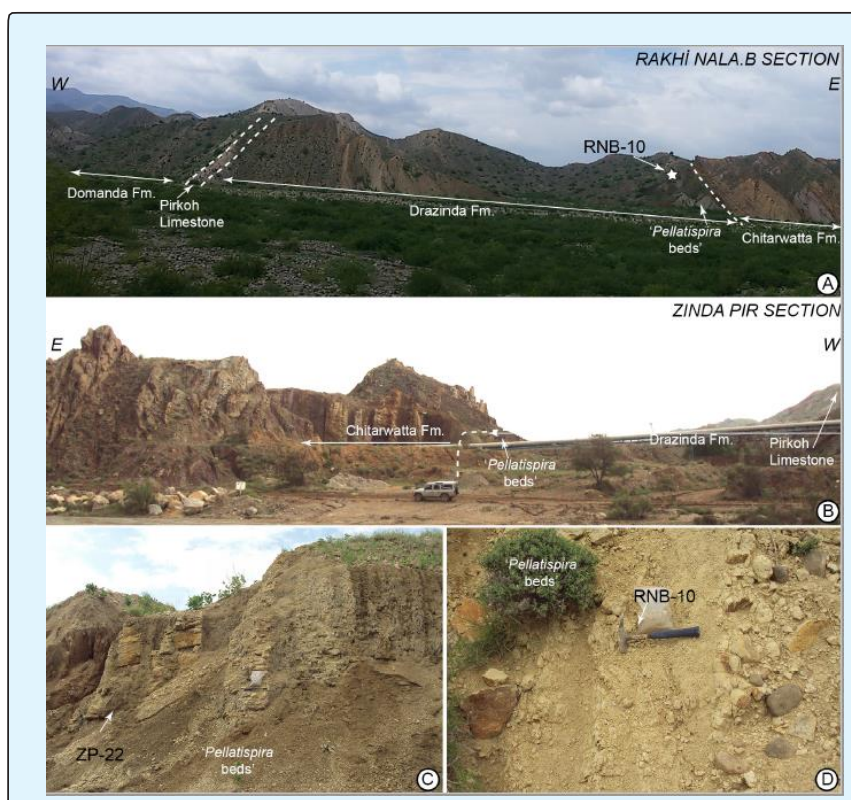

Figure 2: View of Pellatispira-beds in Rakhi Nala.B and Zinda Pir (ZP) sections and sampling points for reticulate Nummulites.

We here carried out a biometric study on the reticulate Nummulites from the Pellatispira-beds of the Drazinda Formation in Sulaiman Fold Belt (west Pakistan) to assess their taxonomy and to compare them with the Western Tethyan reticulate Nummulites with biometric data. The age of the Pellatispira-beds in the uppermost part of the Drazinda Formation, previously invariably assigned to Priabonian, is reinterpreted in the light of new data.

\section{Geological Setting and Age of the 'Pellatispira-Beds' (Drazinda Formation) in the Sulaiman Fold Belt}

The Sulaiman fold belt is a lobate structure in East Pakistan that constitutes a major part of the Lower Indus Basin to the south of the suture zone of the India-Eurasia collision [8] Figures 1A-C. A marine transgression in middle Eocene influenced a large area including the Lower Indus Basin, leading to the deposition of a thick sequence of shallow-marine carbonates and clastics. These deposits contain various marine mammals, decapod crustaceans and abundant larger benthic foraminifera (LBF).

The middle to upper Eocene sedimentary sequence in the Sulaiman Range is subdivided into the Habib Rahi, Domanda, Pirkoh and Drazinda formations, which were collectively named as 'Kirthar' by Blanford [9]. The
Drazinda Formation, more than 380 and 300 m thick in Rakhi Nala and Zinda Pir respectively, consists of darkbrown to greenish-gray shale and subordinate marl and limestone beds containing LBF, bivalves, bryozoans and echinoids in its lower and middle, and pale yellowishgreen Pellatispira-bearing marls in the upper part. Orthophragminids occur abundantly in the lower-middle part of the Drazinda Formation while upper part yields mostly nummulitids, such as Heterostegina, reticulate Nummulites and calcarinids such as Pellatispira and Silvestriella. The Drazinda Formation is unconformably overlain by coastal deltaic to fluvial deposits of the Oligocene Chitarwatta Formation.

The Drazinda formation was previously dated as middle to late Eocene based on calcareous nannofossils [10], planktonic foraminifera [11-13], and larger benthic foraminifera [14-16]. According to Köthe, et al. [10], the age of Drazinda formations in the Rakhi Nala section is Middle Eocene to Priabonian based on nannoplankton zones NP 16-19/20. Samanta [11] recorded Globorotalia crassata/ Truncorotaloides topilensis, Truncorotaloides rohni and Globigerina officinalis zones in the 'Upper Kirthar' Formation in the Rakhi Nala section, suggesting late Middle to late Eocene age for this part of the succession. Afzal, et al. [12] identified P14 planktonic foraminiferal zone in the Drazinda Formation, suggesting (early) Bartonian age for the part of the Drazinda Formation below the Pellatispira-beds. Warraich, et al. [13] identified P13-15 planktonic foraminiferal zones in the Drazinda Formation that suggest a Lutetian/BartonianPriabonian age for this part of the sequence. The upper part of the Drazinda Formation, the Pellatispira-beds, yielded NP18-19/20 calcareous nannofossil assemblages in the Rakhi Nala section pointing out Priabonian age [10]. Özcan, et al. [14,15] assigned a Priabonian age to the Pellatispira-beds based on the occurrence of Silvestriella tetraedra (Gümbel), Pellatispira madaraszi (Hantken), Heterostegina indusensis Özcan, Ali, Hanif, Assilina ex. gr. alpina (Douvillé), Nummulites hormoensis Nuttall \& Brighton and Linderina sp. The Pellatispira-beds also contain the earliest ancestral forms of the genus Baculogypsina (Sacco), which has a stratigraphic range of Pliocene to recent [16]. The Drazinda Formation has been deposited in the shelf lagoon and shoal environments. The Pellatispira-beds of this unit have been deposited in the outer shelf setting [18].

\section{Materials and Methods}

Reticulate Nummulites have been identified only in the upper part of Drazinda Formation ('Pellatispira beds' of Eames, [19]) in two classical sections, the Rakhi Nala (RNB) and Zinda Pir (ZP) sections, located 55 and $35 \mathrm{~km}$ 


\section{International Journal of Paleobiology \& Paleontology}

east and north-west of Dera Ghazi Khan respectively (Figures 1 \& 2). Only the samples RNB-10 (29 $57^{\circ} 16.04^{\prime \prime N}$, 707'11.13"E) and ZP22 (30¹9'56.65"N, 70²9'39.48"E) have yielded reticulate Nummulites. From two samples, after washing and sieving, matrix-free calcarinid specimens could be isolated. Specimens were studied in oriented sections for features, exhibited externally, and in the equatorial layer of the test. The studied material is deposited in the collections of Ercan Özcan at İstanbul Technical University.

\section{Reticulate Nummulites in Western Tethys}

Reticulate Nummulites are common in late middle and upper Eocene shallow marine deposits in Tethys. Because of characteristic features of the test surface, the identification of the group among the nummulids is rather easy, though the species concept is complicated $[2,4,20]$. The most common and rather well known one is the $N$. fabinaii lineage, consisting of several species that are stratigraphically arranged based on the test features and inner cross diameter of proloculus [4] (Table 1, Figure 3).

\begin{tabular}{|c|c|c|c|c|}
\hline Taxon & Pmean $\mathbf{( \mu \mathbf { m } )}$ & Test surface & Age & SBZ zone \\
\hline N. bullatus & $65-100$ & Granules, no reticulation & Late Lutetian to basal Bartonian & SBZ 16 to early 17 \\
\hline N. garganicus & $100-140$ & Heavy granules, reticulation & $\begin{array}{c}\text { Early to middle late Bartonian-basal } \\
\text { Priabonian }\end{array}$ & $\begin{array}{c}\text { late SBZ 17 to SBZ } \\
18 B\end{array}$ \\
\hline N. hormoensis & $140-200$ & $\begin{array}{c}\text { Heavy granules, umbo, } \\
\text { reticulation }\end{array}$ & Latest Bartonian-Early Priabonian & SBZ 18A-C \\
\hline N. fabianii & $200-300$ & $\begin{array}{c}\text { Weak granules, umbo, heavy } \\
\text { reticulation }\end{array}$ & Priabonian to early Rupelian & SBZ 19-21 \\
\hline N. fichteli & $200-300$ & $\begin{array}{c}\text { Weak reticulation to irregular } \\
\text { mesh }\end{array}$ & Late Priabonian to late Rupelian & SBZ 20-22A \\
\hline N. bormidiensis & $300-$ & Irregular mesh & Early Chattian & SBZ 22B \\
\hline
\end{tabular}

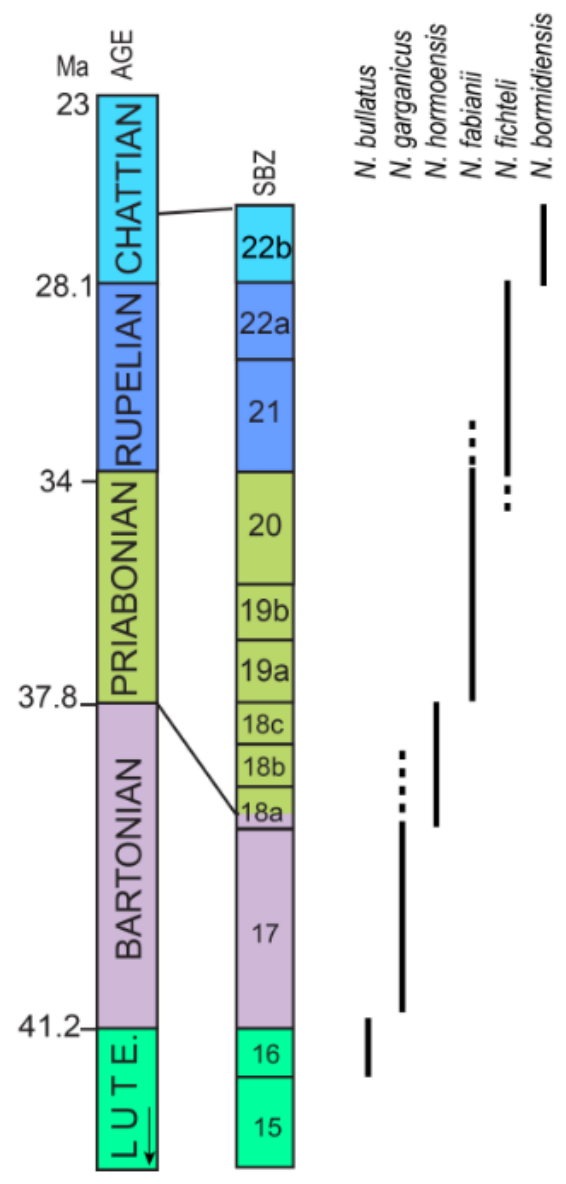

Table 1: Subdivision of $N$. fabianii lineage in Tethys $[3,7]$ and its correlation to shallow benthic zones $[4,7]$. 


\section{International Journal of Paleobiology \& Paleontology}

Although the ancestry to this lineage is not clear, the oldest species appears to be $N$. bullatus with small test

size and proloculus (Figures 3A-C).

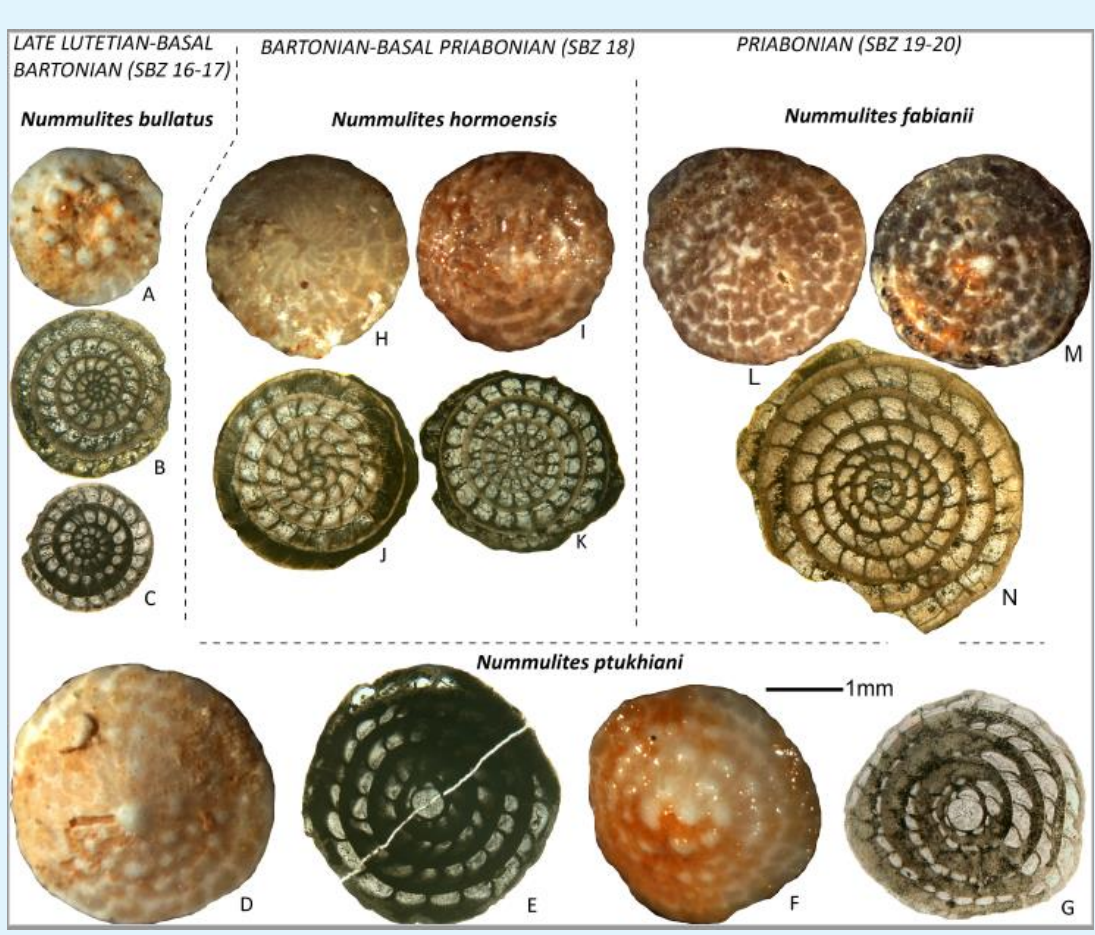

Figure 3: Eocene reticulate Nummulites in Tethys. Specimens in the upper part represent the some species in $N$. fabianii lineage and those in the lower part, N. ptukhiani. Note the changes in granulation and reticulation on the test surface and increase in the inner cross diameter of the proloculus in N. fabianii lineage. Nummulites ptukhiani has a larger proloculus than any species of $N$. fabianii lineage. This species co-occurs with $N$. bullatus in late Lutetian/early Bartonian transitional beds in Oman. A: SE4-20, B: SE12-10, C: SE7-15, D-E: SE4-29, F-G: SE7-11, H: ZP22-49, I: MÜFB9-1, J: RNB10-15, K: MÜFB9-8, L: WM5-32, M: WM5-45, N: WM9-9. SE: Specimens from Seeb Formation, Oman, ZP: from the Pellatispira-beds, Zinda Pir, Pakistan, RNB: from the Pellatispira-beds, Rakhi Nala, Pakistan, WM5: from Tahwah Formation, Wadi Musawa, Oman.

This species doesn't have reticulation but coarse granules in the central part of the test and is confined to upper Lutetian-basal Bartonian beds in Tethys. The reticulation becomes significant in the following stages in $N$. hormoensis and $N$. fabianii during Bartonian and Priabonian, whereas $N$. fichteli in Rupelian displays rather irregular mesh structure at the test surface. Meantime, granules become weak in Rupelian and early Chattian species, $N$. fichteli and $N$. bormidiensis. The inner crossdiameter of the proloculus appears to be the most significant evolutionary parameter to subdivide the $N$. fabianii lineage into species (Table 1). The increase of the average length of chambers in the third whorl is of secondary importance in recognizing the evolution of the group because it is affected also by ecological factors. The tightness/laxity of the spire and the relative width of the spiral cord in the third whorl are the functions of the paleoenvironment. Nummulites ptukhiani, originally described from Armenia, has large granules, reticulation and a much larger proloculus than any species of $N$. fabianii lineage (Figures 3D-G). We have identified this species in the same beds with $N$. bullatus in Oman. It appears that Nummulites ptukhiani belongs to another reticulate Nummulites lineage, which requires further studies to understand its phylogeny.

\section{Results and Interpretation}

The reticulate Nummulites specimens in two samples (ZP22 and RNB10) from Pellatispira-beds have a test 


\section{International Journal of Paleobiology \& Paleontology}

diameter ranging from 1.49 to $3.2 \mathrm{~mm}$. The surface of the test is heavily reticulated with very weak granulation (Figures 4 A, E, I, M, Q). Most specimens possess a central boss (a thick granule) (Figures $4 \mathrm{~A}, \mathrm{E}, \mathrm{I}, \mathrm{M}$ ). The rounded proloculus is followed by a second chamber, which is slightly compressed along the axis of proloculus and second chamber. Second chamber is either same size or slightly smaller than the proloculus. The proloculus diameter in ZP22 and RNB10 ranges between 100-240 and 110-200 $\mu \mathrm{m}$ respectively (Table 2). The average inner-cross diameter in ZP22 and RNB10 is 152.0 and $153.0 \mu \mathrm{m}$ respectively (Table 2 , Figure 5 ). The chambers are arranged in 4 to 7 whorls. According to the innercross diameter, the specimens from both samples are assigned to $N$. hormoensis (Figure 5). However, the granulation in both samples is very weak.

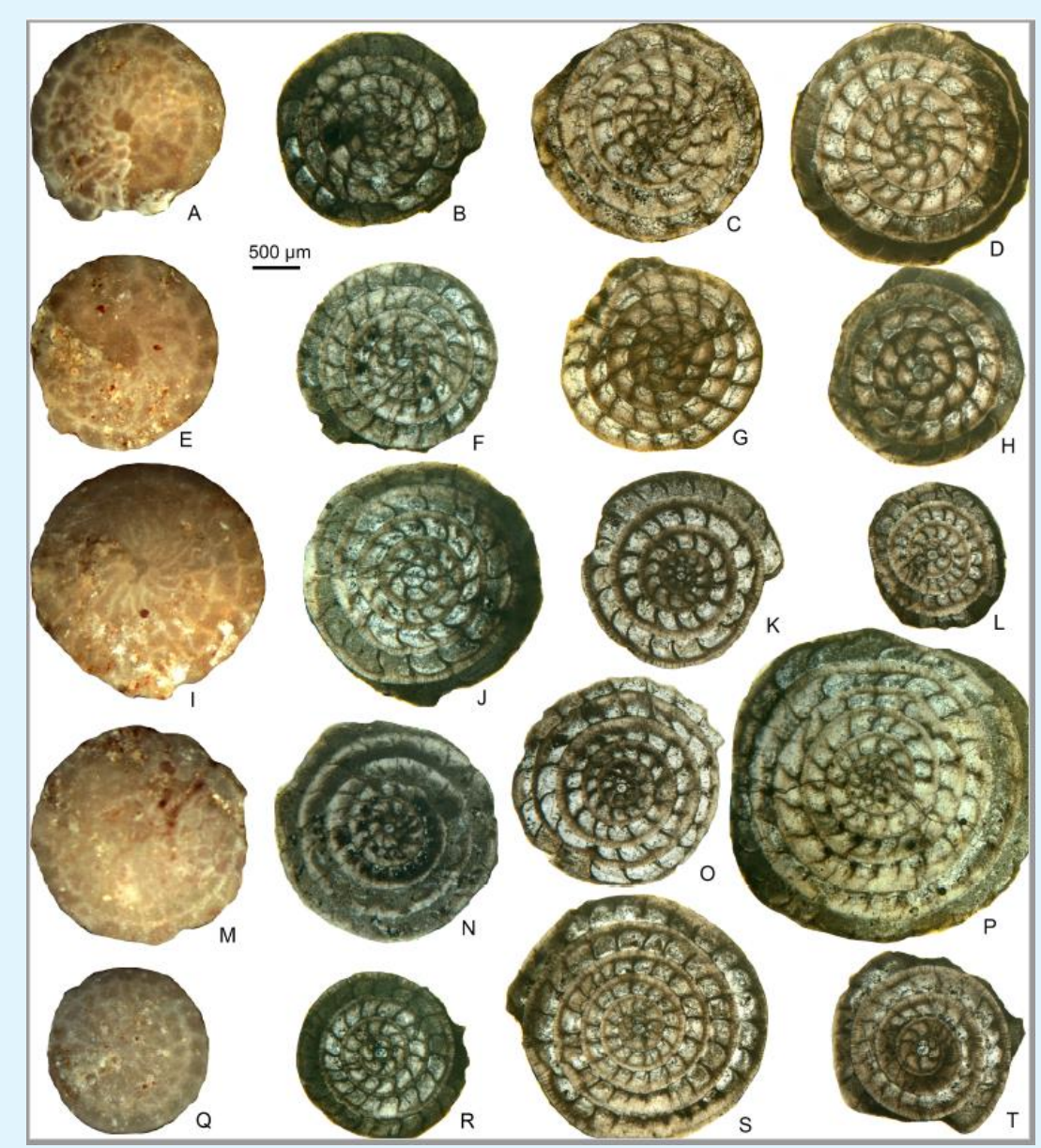

Figure 4: External views (A, E, I, M, Q) and equatorial sections (B-D, F-H, J-L, N-P, R-T) of reticulate Nummulites from the Pellatispira-beds. A-B: ZP22-39, C: RNB10-14, D: RNB10-15, E-F: ZP22-41, G: RNB10-18, H: RNB10-53, I-J: ZP2249, K: ZP22-89, L: ZP22-87, M-N: ZP22-50, 0: ZP22-92, P: ZP22-62, Q-R: ZP22-53, S: ZP22-94, T: ZP22-81.

\begin{tabular}{|c|c|c|c|c|c|c|c|c|c|c|}
\hline \multirow{3}{*}{ Parameters } & \multicolumn{3}{|c|}{ Proloculus } & \multicolumn{3}{|c|}{ First two whorls } & \multicolumn{4}{|c|}{ Third whorl } \\
\hline & \multirow{2}{*}{\multicolumn{3}{|c|}{$\begin{array}{c}\text { diameter } \\
P(\mu \mathrm{m})\end{array}$}} & \multirow{2}{*}{\multicolumn{3}{|c|}{$\begin{array}{c}\text { diameter } \\
\mathrm{d}(\mu \mathrm{m})\end{array}$}} & \multicolumn{4}{|c|}{ average length of chambers } \\
\hline & & & & & & & & $\mathrm{L}=\mathrm{d} \times \pi / \mathrm{N}$ & & \\
\hline Sample & \multicolumn{3}{|c|}{\begin{tabular}{l|l} 
range & mean \pm s.e.
\end{tabular}} & № & range & mean \pm s.e. & № & range & \multicolumn{2}{|c|}{ mean \pm s.e. } \\
\hline RN.B-10 & 8 & $110-200$ & $153 \pm 11$ & 6 & $875-1200$ & $1058 \pm 51$ & 6 & $172-237$ & 219 & \pm 9 \\
\hline ZP.22 & 22 & $100-240$ & $152 \pm 8$ & 16 & $750-1385$ & $1059 \pm 41$ & 12 & $157-263$ & 203 & \pm 9 \\
\hline
\end{tabular}

Table 2: Statistical data of Nummulites hormoensis from samples ZP22 and RNB10. 


\section{International Journal of Paleobiology \& Paleontology}

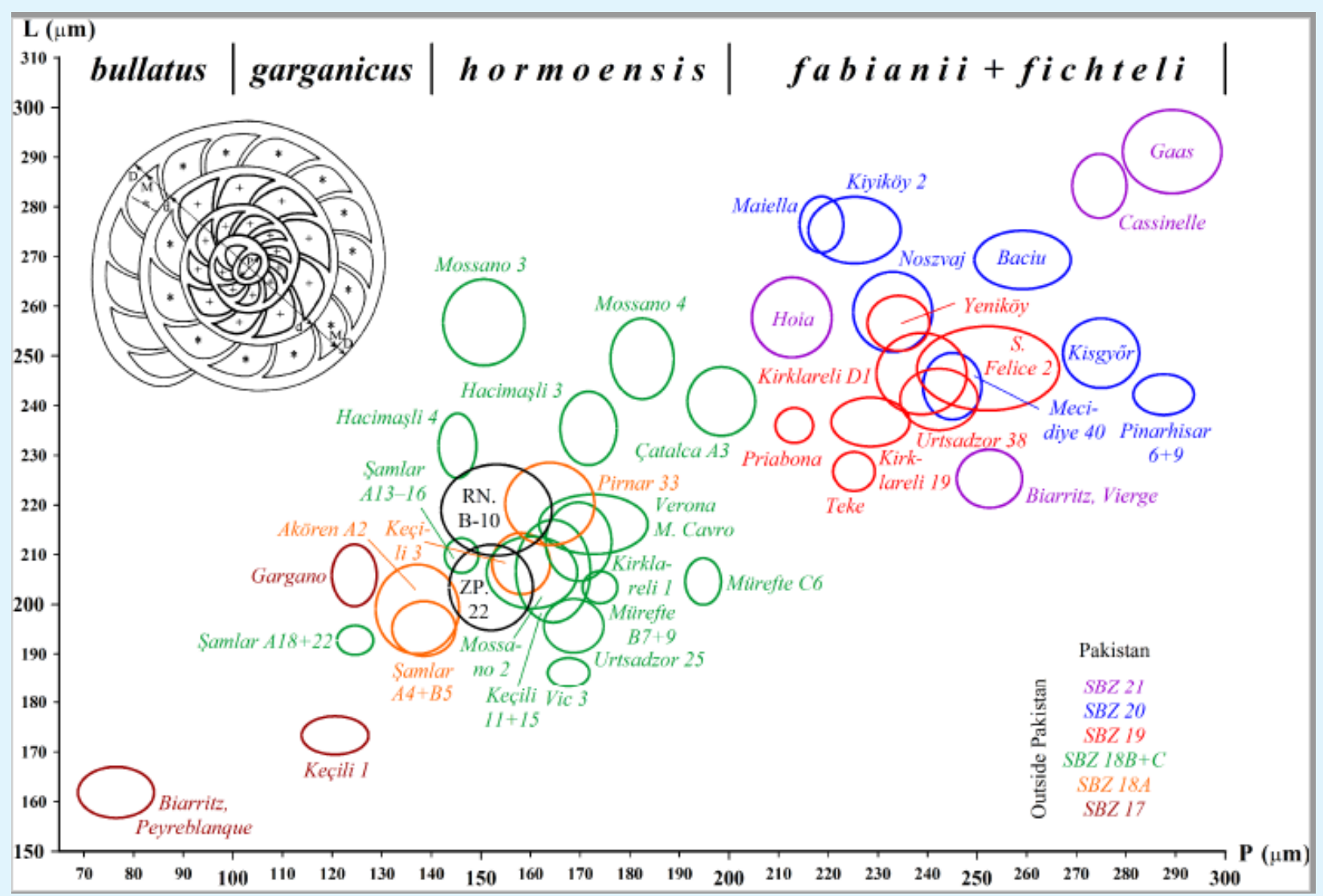

Figure 5: Bivariate P-L plot (proloculus diameter versus chamber length in the third whorl) for Eocene reticulate Nummulites populations from the Pellatispira-beds and some other localities $[4,5,7,20]$ in the Tethys.

The stratigraphic range of $N$. hormoensis extends from shallow benthic zone (SBZ) 18A to 18C, which are referable to latest Bartonian and early Priabonian time interval after the modifications of Bartonain-Priabonian boundary with respect to time scale and its reinterpretation by Papazzoni, et al. [20]). The Bartonian/Priabonian boundary is recently in the process of its redefinition and it is placed at a lower stratigraphic level as to include much of the Upper Bartonian [22]. This interpretation, shown in Table 1 , requires that $N$. hormoensis in Western Tethys is mostly confined to the early Priabonian. The associated larger foraminifera in the Pellatispira-beds are represented by Silvestriella tetraedra (Gümbel), Pellatispira madaraszi (Hantken), Heterostegina indusensis Özcan, Ali, Hanif, Assilina ex. gr. alpina (Douvillé), Linderina sp. and Baculogypsina n. sp. Figure 6. Heterostegina specimens in the Pellatispira beds in Zinda Pir and Rakhi Nala, represent a single homogenous population, characterised by a small, nearly flat to centrally slightly inflated test with characteristic surface granules, a small proloculus, and relatively tight early spirals Figure 6L-P. These specimens are not comparable to those from the Bartonian-Priabonian Heterostegina in the Western Tethys and Priabonian of Indo-Malayan region and Pacific, and thus a new species, $H$. indusensis $\mathrm{n}$. sp., was created by Özcan, et al. [14]. Therefore, application of evolutionary scheme of $H$. reticulata lineage [4] for a high-resolution dating of the Priabonian deposits of the Sulaiman range is not possible. 


\section{International Journal of Paleobiology \& Paleontology}

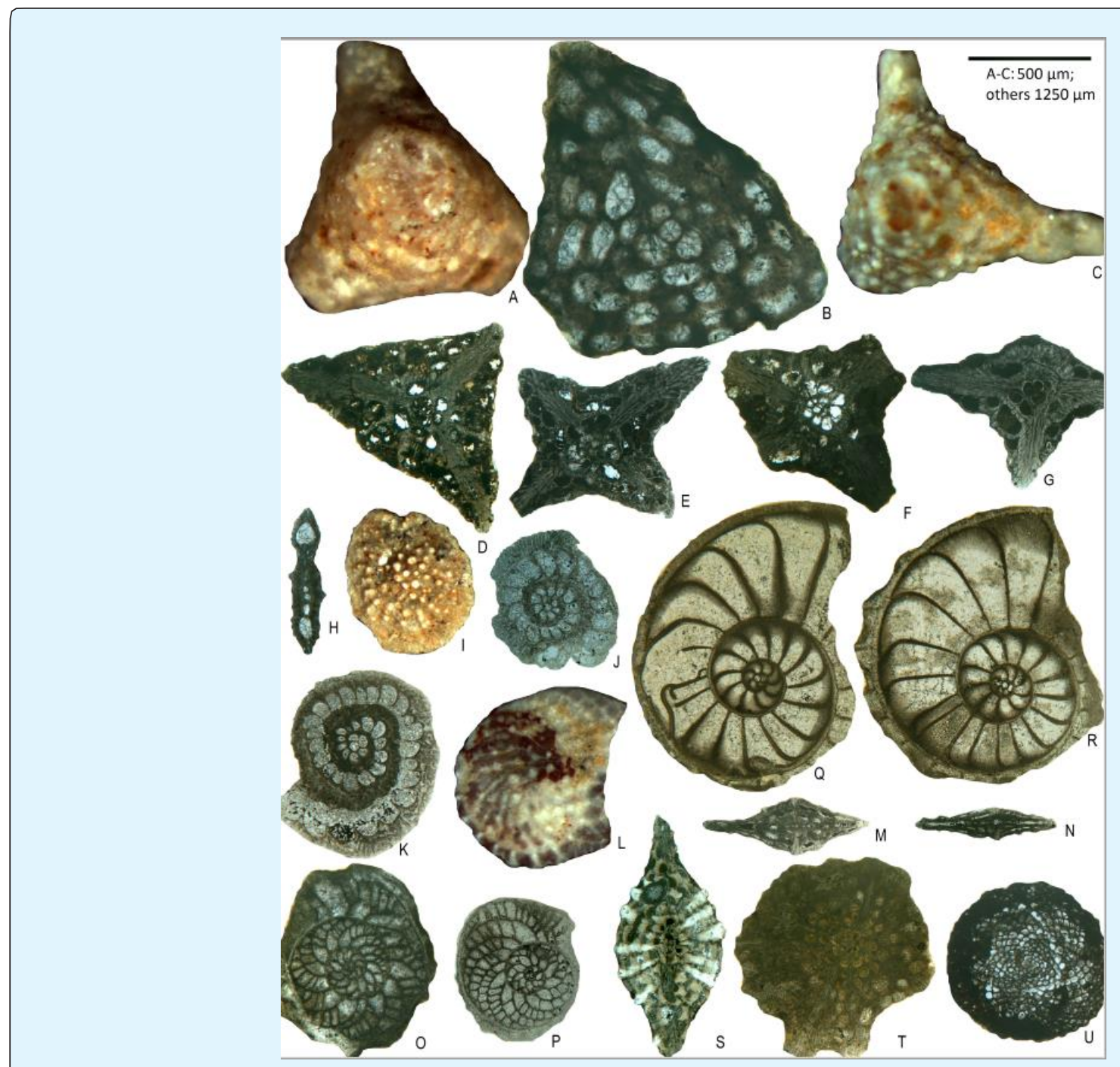

Figure 6: Stratigraphically significant larger benthic foraminifera in the Pellatispira-beds. (A-G) Silvestriella tetraedra (Gümbel), A-B: ZP22-45, C: ZP22-119, D: DB5-1, E: DB5-2, F: DB5-3, G: DB5-4. (H-K) Pellatispira madaraszi (Hantken), H-I: RNB11-50, J: ZP22-46, K: ZP23-5. (L-P) Heterostegina indusensis Özcan, Ali, Hanif, L: ZP22-38, M: ZP22-100, N: ZP22-104, O: ZP22-74, P: ZP22-39. (Q-R) Assilina ex. gr. alpina (Douvillé), Q: RNB11-3, R: RNB11-33. (S-T) Baculogypsina n. sp., S: ZP22-78, T: ZP22-76. (U) Linderina sp. DB5-6. Note DB refers to a stratigraphic section (Domando Bridge) near D.I. Khan. Pellatispira-beds don't contain reticulate Nummulites but typical Priabonian fauna.

\section{Conclusion}

We for the first time present the biometric data of the reticulate Nummulites from the Priabonian of Pakistan. The reticulate Nummulites in the Pellatispira-beds have a small proloculus, in the range of 'primitive developmental stage' of $N$. hormoensis Nuttall and Brighton, a latest Bartonian- early Priabonian species in the Western Tethys sensu Less and Özcan [4]. This species is associated with Silvestriella tetraedra (Gümbel), Pellatispira madaraszi (Hantken), Heterostegina indusensis Özcan, Ali, Hanif, Assilina ex. gr. alpina (Douvillé), Linderina sp. and Baculogypsina n. sp. It is likely that Nummulites fabianii lineage shows a uniform distribution from peri-Mediterranean region to the Indian subcontinent and application of the biometric scheme of whole lineage may be possible in this part of the Tethys. This requires further studies on the primitive and advanced members of the lineage in a stratigraphic context. Our results provide information only for a part of the lineage and should be complimented by further data collected from different stratigraphic levels in the 


\section{International Journal of Paleobiology \& Paleontology}

Priabonian of the Indian subcontinent. We think that the age of Pellatispira-beds doesn't cover the whole Priabonian but only early Priabonian following the redefined correlation of the Bartonian-Priabonian boundary with geological time scale. Our data show that reticulate Nummulites have the potential for biostratigraphic applications in a wide area in the Tethys.

\section{Acknowledgments}

We are grateful to National Centre of Excellence in Geology, University of Peshawar, for providing travel support for the field work in the Sulaiman fold belt, West Pakistan.

\section{References}

1. Samanta BK, Bandopadhyay KP, Lahiri A (1990) The occurrence of Nummulites Lamarck (Foraminiferida) in the middle Eocene Harudi Formation and the Fulra limestone of Cutch, Gujarat, Western India. Bulletin of the Geological, Mining \& Metallurgical Society of India 55: 1-66.

2. Papazzoni CA (1998) Biometric analyses of Nummulites "ptukhiani" Z. D. Kacharava, 1969 and Nummulites fabianii (Prever in Fabiani, 1905). Journal of Foraminiferal Research 28(3): 161-176.

3. Özcan E, Less G, Okay AI, Baldi-Beke M, Kollanyi K, et al. (2010) Stratigraphy and Larger Foraminifera of the Eocene Shallow-marine and Olistostromal Units of the Southern Part of the Thrace Basin, NW Turkey. Turkish Journal of Earth Sciences 19: 27-77.

4. Less G, Özcan E (2012) Bartonian-Priabonian larger benthic foraminiferal events in the Western Tethys. Austrian Journal of Earth Sciences 105/1: 129-140.

5. Cotton LJ, Zakrevskaya EY, van der Boon A, Asatryan G, Hayrapetyan F, et al. (2017) Integrated stratigraphy of the Priabonian (upper Eocene) Urtsadzor section, Armenia. Newsletters on Stratigraphy 50/3: 269-295.

6. Saraswati PK, Anwar D, Lahiri A (2017) Bartonian reticulate Nummulites of Kutch. Geodinamica Acta 29(2): 14-23.

7. Less G, Frijia G, Özcan E, Saraswati PK, Parente M, et al. (2018) Nummulitids, lepidocyclinids and Srisotope data from the Oligocene of Kutch (western India) with chronostratigraphic and paleobiogeographic evaluations. Geodinamica Acta 30(1): 183-211.
8. Kazmi AH, Rana RA (1982) Tectonic map of Pakistan. Geological Survey of Pakistan.

9. Blanford WT (1879) The Geology of Western Sind: Memoirs of the Geological Survey of India 17: 1-210.

10. Köthe A, Khan AA, Ashraf M (1988) Biostratigraphy of the Surghar Range, Salt Range, Sulaiman Range and the Kohat area, Pakistan, according to Jurassic through Paleogene calcareous nannofossils and Paleogene dinoflagellates. Geologisches Jahrbuch B71: 1-87.

11. Samanta BK (1973) Planktonic foraminifera from the Palaeocene-Eocene succession in the Rakhi Nala, Sulaiman Range, Pakistan. Bulletin of the British Museum (Natural History), Geology 22: 423-482.

12. Afzal J, Asrar MK, Naseer AS (1997) Biostratigraphy of the Kirthar Formation (Middle to Late Eocene), Sulaiman Basin, Pakistan. Pakistan Journal of Hydrocarbon Research 9: 15-33.

13. Warraich MY, Nishi H (2003) Eocene planktic foraminiferal biostratigraphy of the Sulaiman Range, Indus Basin, Pakistan. Journal of Foraminiferal Research 33(3): 219-236.

14. Özcan E, Ali N, Hanif M, Hashmi SI, Khan A, et l. (2016) New Priabonian Heterostegina from the Eastern Tethys (Sulaiman fold belt, West Pakistan): implications for the development of Eastern Tethyan heterostegines and their paleobiogeography. Journal of Foraminiferal Research 46(4): 393-408.

15. Özcan E, Saraswati PK, Hanif M, Ali N (2016) Orthophragminids with new axial thickening structures from the Bartonian of the Indian subcontinent. Geologica Acta 14(3): 261-282.

16. Özcan, E, Hohenegger J, Yücel AO, Kayğılı S, Ali N, Hanif $M$ (in review) Baculugypsina sulaimanensis $n$. sp., from the Priabonian of Sulaiman Range, Pakistan, an ancestor for the recent Baculogypsina sphaerulata. Journal of Foraminiferal Research.

17. Ali N, Özcan E, Yücel AO, Hanif M, Hashmi SI, et al. (2018) Bartonian orthophragminids with new endemic species from the Pirkoh and Drazinda formations in the Sulaiman Range, Indus Basin, Pakistan. Geodinamica Acta 30: 31-62.

18. Abbas G (1999) Microfacies, depositional environments, diagenesis and porosity development in Limestone horizons of Kirthar Formation (Middle- 


\section{International Journal of Paleobiology \& Paleontology}

Late Eocene) in frontal parts of Sulaiman fold belt and adjoining areas, Pakistan. Ph.D. Thesis. University of Punjab, pp: 112.

19. Eames FE (1952) A contribution to the study of the Eocene in western Pakistan and western India: A. The geology of standard sections in the western Punjab and in the Kohat district. Quarterly Journal of the Geological Society 107: 159-171.

20. Cotton LJ, Pearson PN, Renema W (2015) A new Eocene lineage of reticulate Nummulites (foraminifera) from Kilwa district, Tanzania: a place for Nummulites ptukhiani? Journal of Systematic Palaeontology 14(7): 569-579.
21. Papazzoni CA, Cosovic V, Briguglio A, Drobne $\mathrm{K}$ (2017) Towards a calibrated larger foraminifera biostratigraphic zonation: celebrating 18 years of the application of shallow benthic zones. Palaios 32: 1-4.

22. Costa E, Garcés M, López-Blanco M, Serra-Kiel J, Bernaola L, Cabrera L, Beamud E (2013) The Bartonian-Priabonian marine record of the Eastern South Pyrenean Foreland Basin (NE Spain): A new calibration of the larger foraminifers and calcareous nannofossil biozonation. Geologica Acta 11(2): 177193. 